\title{
ESKETAMINAS IR GYDYMUI ATSPARI DEPRESIJA
}

\author{
Vidmantas Grigas \\ Lietuvos sveikatos moksly universiteto Medicinos akademijos Medicinos fakultetas
}

Raktažodžiai: didysis depresinis sutrikimas, gydymui atspari depresija, esketaminas.

\section{Santrauka}

Tyrimo tikslas. Apžvelgti ir apibendrinti įrodymais grịstos medicinos duomenis apie esketamino naudingumą ir pritaikymą gydyti gydymui atsparią depresiją . Apžvelgti medikamento farmakologinị veikimo mechanizmą, klinikinį naudingumą bei pateikti klinikines medikamento skyrimo rekomendacijas, siekiant užtikrinti tinkamą bei saugų preparato vartojimą.

Metodika. Atlikta teminių mokslinių straipsnių paieška Pubmed, SpringerLink duomenų bazèse, naudojant reikšminius žodžius: didysis depresinis sutrikimas, gydymui atspari depresija, esketaminas. Iš daugiau nei 70 mokslinių publikacijų atrinkta 30 straipsnių. Rezultatai. İvardinta gydymui atsparios depresijos problematika. Apžvelgtas atsparios depresijos gydymui vartojamo medikamento esketamino veikimo mechanizmas, klinikinis naudingumas bei pateiktos klinikinès rekomendacijos specialistams, medicinineje praktikoje skiriantiems esketaminą rezistentiškos depresijos gydymui. Išvados. Esketaminas, vartojamas kartu su kitu, naujai paskirtu SSRI ar SNRI grupès geriamuoju antidepresantu, yra efektyvus preparatas, tinkamas gydyti gydymui atsparią depresiją. Ankstesnès terapijos metu, skiriant gydymą bent dviem skirtingais antidepresantais, tinkamomis dozėmis ir pakankamą gydymo laiką, depresijos simptomai nesumažejo. Pacientams, vartojantiems esketaminą, stebima mažesnè depresijos recidyvo rizika. Esketaminas mažina gydymui atsparia depresija sergančių pacientų savižudybès riziką. Medikamentas vartojamas sveikatos specialisto priežiūroje. Po preparato inhaliacijos pacientas stebimas 2 valandas ir vertinama, ar nepasireiškia ankstyvieji, po medikamento pavartojimo atsiradandantys nepageidaujami reiškiniai: arterinè hipertenzija, disociaciniai (konversiniai) sutrikimai bei sedacinis poveikis. Užtikrinus tinkamą ankstyvujų nepageidaujamų reiškinių kontrolę ir paciento stebėseną, esketaminas yra saugus preparatas gydyti gydymui atsparią depresiją.

\section{Ivadas}

Didysis depresinis sutrikimas yra reikšminga sveikatos priežiūros problema visame pasaulyje, pasireiškianti dideliais sergamumo ir mirtingumo rodikliais, didinanti savižudybių ar mèginimų nusižudyti riziką[1]. Ši liga reikšmingai sutrikdo tarpasmeninius individo santykius ir neigiamai paveikia paciento produktyvumą kasdienejje veikloje, sukelia finansinę naštą individui ir visuomenei [1]. $2017 \mathrm{~m}$. Pasaulio sveikatos organizacijos duomenimis, šiuo sutrikimu sirgo apie 300 milijonų žmonių visame pasaulyje. Atliktų tyrimų duomenimis nustatyta, jog didysis depresinis sutrikimas 4,3 proc. padidina ankstyvojo mirtingumo ar ilgalaikio gyvenimo su negalia riziką. Prognozuojama, jog iki 2030 metų šio sutrikimo dažnis tik didès. Sergančiųų didžiuoju depresijos sutrikimu padidejusi savižudybės rizika, kuri svyruoja nuo 2 iki 15 procentų [2]. Remiantis JAV nacionalinès epidemiologinès apklausos dèl alkoholio vartojimo ir su juo susijusių ligų (NESARC III) 2012-2013 metų duomenimis, pacientai, vartojantys alkoholi ar kitas psichoaktyviąsias medžiagas, turejo 20,6 proc. riziką per visą savo gyvenimo laikotarpi nors sykị susirgti didžiuoju depresiniu sutikimu [1].

Nepaisant taikomo antidepresnio gydymo, daugeliui didžiuoju depresijos sutrikimu sergančių pacientų nepavyksta pasiekti ilgalaikès klinikinès simptomų remisijos. Stipriai išreikšti depresijos simptomai susiję su nuolatiniu paciento funkciniu sutrikimu, didesniu sveikatos priežiūros išteklių naudojimu, didesne savižudybės rizika ir bendru padidejjusiu mirtingumu, ypač susijusiu su širdies ir kraujagyslių ligomis [3]. Nors prieš pusšimtị metų sukurti monoaminerginiai antidepresantai sukèlè didžiulị perversmą depresijos sutrikimų gydyme, maždaug trečdaliui didžiuoju depresijos sutrikimu sergančių pacientų neišgaunama teigiamo klinikinio atsako, taikant ịprastinị depresijos gydymą [4]. Gydymui atspari depresija (GAD) yra didžiosios depresijos sutrikimo pogrupis, neatsakantis ị tradicinius pirmaeilio gydymo metodus [5]. Literatūroje išskiriama keletas gydymui atsparios depresijos 
apibrež̌imų ir grupavimo modelių, tačiau bendro sutarimo dèl ligos apibrèžimo dar nepasiekta. Remiantis skirtingu gydymui atparios depresijos modelių bedrybėmis, stebimas nepakankamas gydomasis atsakas ị mažiausiai 2 skiriamų antidepresantų gydymo ciklus [5]. Taikomos gydymo strategijos asmenims, sergantiems gydymui atsparia depresija, apima gydymą maksimaliomis skiriamų antidepresantų dozėmis, pridedant papildomą antidepresantą, pridedant antipsichotinių vaistu prie jau vartojamo antidepresanto arba skiriant naują antidepresantą [6]. Daugeliui pacientų nepasiekiamas terapinis gydymo efektas arba pasireiškia su medikamentų netoleravimu susiję reiškiniai. Sunkiausiai gydomiems pacientams gali būti naudojama elektrokonvulsinè terapija (EKT) ir transkranijinè magnetinè stimuliacija (TMS). EKT ir TMS turi didelių klinikinių ar logistinių apribojimų, dél kurių sunku užtikrinti ilgalaiki gydymą depresija sergantiems pacientams. Atsižvelgiant ị šias terapines problemas, buvo pradèta ieškoti naujų rezistentiškos gydymui depresijos gydymo metodų [6].

Inovatyviausia sunkios depresijos valdymo naujovè intranazaliai vartojamas, depresijos simptomus mažinančiu poveikiu pasižymintis preparatas esketaminas, teikia daug žadančių galimybių gydant rezistentišką depresiją [7]. Iprastų peroralinių antidepresantų gydomajam efektui pasiekti paprastai prireikia savaičiu ar net mènesių, o ši naujoji depresijos gydymo alternatyva pasižymi greitu nuotaiką gerinančiu poveikiu[7]. Ketamino anestetinis ir raminamasis poveikis yra išsamiai išnagrinètas. Intranazalinis ketaminas naudojamas kaip viena iš anestetinių pasirinkimo priemonių pacientams, patyrusiems ūminị sužalojimą, esant vidutinio sunkumo ar stipriam skausmui ekstremaliomis sąlygomis [8]. Pastebèta, jog intranazalinio ketamino vartojimas mažomis dozėmis pasižymi nuotaiką gerinančiu poveikiu ir su gydymu susijusiais nežymiai išreikštais nepageidaujamais reiškiniais [9]. Nustatyta, jog mažos, anestetinio poveikio nesukeliančios ketamino koncentracijos sukelia neuropsichologini poveikị ir pasireiškia greitu nuotaiką gerinančiu efektu [10].

Tyrimo tikslas - apžvelgti ir apibendrinti įrodymais grịstos medicinos duomenis apie esketamino naudingumą ir pritaikymą gydyti gydymui atsparią depresiją . Apžvelgti medikamento farmakologinị veikimo mechanizmą, klinikinị naudingumą bei pateikti klinikines medikamento skyrimo rekomendacijas, siekiant užtikrinti tinkamą bei saugų preparato vartojimą.

\section{Tyrimo medžiaga ir metodai}

Atlikta teminių mokslinių straipsnių paieška Pubmed, SpringerLink duomenų bazėse, naudojant reikšminius žodžius: didysis depresinis sutrikimas, gydymui atspari depre- sija, esketaminas. Iš daugiau nei 70 mokslinių publikacijų analizei atrinkta 30 straipsnių.

\section{Tyrimo rezultatai}

Didysis depresijos sutrikimas ir gydymui atspari depresija. Remiantis DSM-5 didžiojo depresinio sutrikimo kriterijais, DDS diagnozuojamas, kuomet pasireiškia $\geq 5$ iš žemiau išvardintų simptomų, kurie pasireiškia beveik kiekvieną dieną, ilgiau nei 2 savaites [11].

- Liūdna nuotaika ir (arba) anhedonija.

- Žymūs svorio pokyčiai (>5 proc. svorio per mènesį).

- Sumažèjęs apetitas.

- Insomnija ar hipersomnija.

- Psichomotorinis sujaudinimas ar slopinimas.

- Nuovargis ar energijos stoka.

- Nevisavertiškumo ir kaltės idejos.

- Dėmesio koncentracijos sutrikimas.

- Mintys apie savižudybę.

Didysis depresijos sutrikimas, kuris neišnyksta skiriant tinkamą gydymą antidepresantais, vadinamas gydymui atsparia depresija. Atsparumą gydymui gali lemti keletas veiksnių, įskaitant neatpažintas gretutines somatines ar psichines ligas, poligramazija, netinkamą medikamento pritaikymą ir psichosocialinius stresogeninius veiksnius [12]. Senesnių literatūros šaltinių teigimu, gydymui atsparios depresijos kriterijus sudare: nesėkmingas gydymas vienu pacientui tinkamu antidepresantu adekvačiomis dozèmis ir trukme, nesėkmingas gydymas dviem pacientui tinkančiais antidepresantais adekvačiomis dozèmis ir trukme, nesėkmingas gydymas monoaminooksidazès inhibitoriumi, ličiu, heterocikliais antidepresantais, ar nesėkmingas bent vienas elektrokonvulsinio gydymo seansas [13]. Šiuo metu, remiantis 2019 metų EMA (European Medicines Agency) sutarimu, gydymui atspari depresija nustatoma, jei nèra terapinio depresijos gydymo efekto gydant bent dviem skirtingais antidepresantais tinkamomis dozèmis ir pakankamą gydymo laiką [14].

Kas yra esketaminas? Ketaminas - tai racematinis $\mathrm{S}(+)$ ketamino ir R(-) ketamino izomerų (entantiomerų) mišinys. Šie entantiomerai pasižymi panašiomis farmakokinetinèmis savybėmis, tačiau $\mathrm{S}(+)$ ketamino izomeras 3 kartus efektyvesnis už R(-) ketamino formą, ji vartojant anestezijai ir analgezijai [15]. Esketaminas, ketamino S-enantiomeras - tai N-metild-aspartato receptorių antagonistas, kuris, vartojamas antidepresanto dozių (mažų dozių) intervale, laikinai padidina glutamaterginį signalo perdavimą, dèl kurio ivyksta $\alpha$-amino-3-hidroksi-5-metil-4 -izoksazolepropiono rūgšties receptorių aktyvacija . Esketamino nosies purškalas (Spravato ${ }^{\mathrm{TM}}$ ) buvo patvirtintas naudoti kartu su geriamuoju antidepresantu, gydant gydymui atsparią depresiją JAV, Europoje ir daugelyje kitų šalių [16]. 
Veikimo mechanizmas. Ketaminas turi dideli afinitetą NMDA receptoriaus inotropiniam kanalui, kur jis veikia antagonistiškai ir sukelia NMDA receptorių blokadą. Ketaminui užblokavus NMDA receptorius, glutamatas, sąveikoje su AMPA receptoriais, didina jų pralaidumą. Padidejęs AMPA receptoriu pralaidumas sukelia ketamino antidepresini poveiki, o greitas terapinis efektas pasiekiamas dèl didelio AMPA receptorių aktyvumo padidejimo ir sąlyginio NMDA receptorių pralaidumo sumažèjimo [17]. Tyrejjų teigimu, sergantieji didžiuoju depresiniu sutrikimu, turi didesnius nervinio signalo perdavejjo glutamato kiekius centrinejje nervų sistemoje, o jo padidejimas tiesiogiai susijęs su stipriau išreikšta depresine simptomatika. Dèl to ketaminas buvo pasiūlytas kaip galima greito poveikio ir veiksminga alternatyva gydyti gydymui atsparią depresiją [18].

Vartojimas. Pacientas, stebimas sveikatos priežiūros specialisto, i kiekvieną nosies šnervę ịsipurškia (po 1 ịpurškimą) esketamino. Suminè preparato dozė ị abi šnerves atitinka $28 \mathrm{mg}$ esketamino. $56 \mathrm{mg}$ dozei naudojami 2 nosies ịpurkšimo prietaisai. Atitinkamai, 84 mg dozei - 3 purkšimo prietaisai. Po kiekvieno prietaiso panaudojimo pacientai turi 5 minutes pailsèti. Pradinè esketamino dozė yra 56 miligramai pirmają dieną, o paskesnès $56 \mathrm{mg}$ ar $84 \mathrm{mg}$ dozès per 1-4 savaites skiriamos kartu su geriamuoju antidepresantu [19]. Dozès parinkimas ir dozavimo dažnis priklauso nuo veiksmingumo, toleravimo ir yra individualizuoti, kad būtu galima kuo rečiau dozuoti, išlaikant atsaką ir remisiją. Gavę dozę, pacientai stebimi 2 valandas, kad būtų galima nustatyti bet kokị neigiamą poveiki, pvz., hipertenziją, sedaciją ir atsiribojimą. Esketamino nerekomenduojama vartoti pacientams, kuriems yra sunkus kepenų funkcijos sutrikimas [19].

Klinikinis naudingumas. 2018 m. E. Daly ir kolegų atlikto tyrimo metu, intranazalinis esketaminas arba placebo buvo vartojamas dukart per savaitę pirmąsias dvi savaites. Kitas tris savaites preparatas buvo vartojamas vienąkart per savaitę. Vèliau - vienąkart kas dvi savaites. Atsako ị gydymą vertinimas atliktas 74 gydymo dieną. Remiantis Montgomerio-Asbergo depresijos vertinimo skale (MADRS), 65 procentai tyrime dalyvavusiujų pacientų, pakartotinai įvertinus depresijos išreikštumo simptomus, pasiekè didesnę nei 50 proc. depresijos simptomų redukciją. 32 proc. tiriamụjų 74 tyrimo dieną turèjo 10 balų ar mažesnius MADRS ịverčius, o tai parodo, jog depresijos simptomai išnyko, ar atitiko lengvos depresijos kriterijus [20]. Kitų autorių tyrimų duomenimis, MADRS depresijos vertinimo skalès ịverčiai reikšmingai sumažejo jau po 4 valandų nuo intranazalinio esketamino pavartojimo. Stebèta sumažejusi suicidinių minčių ar ketinimų nusižudyti rizika. Lyginant su placebo grupe, statistiškai reikšmingas depresijos simptomų palengvejimas buvo stebimas per visą keturių savaičių gydymo laikotarpị.
Statistiškai reikšminga depresijos simptomų redukcija stebèta praejus atitinkamai 24 valandoms, 3 ir 11 dienų nuo esketamino vartojimo pradžios [21]. $2018 \mathrm{~m}$. V. Popovos ir kolegų aprašytame TRANSFORM-2 3 fazès randomizuotame, dvigubai slaptame tyrime buvo ịvertintas intranazalinio esketamino efektyvumas gydant pacientus, sergančius gydymui atsparia depresija. Visų atrinktų tyrimo dalyviu anamnezeje buvo gydymui atspari depresija, kai teigiamo gydymo efekto nebuvo pasiekta vartojant nors vieną peroralini antidepresantą. Neefektyvus peroralinis antidepresantas buvo pakeistas kitu peroraliniu antidepresantu, kartu paskiriant 28 $\mathrm{mg}, 56 \mathrm{mg}$ ar $86 \mathrm{mg}$ intranazalinio esketamino dozę arba intranazalini placebo. Remiantis tyrimo rezultatais, 28 gydymo dieną buvo stebetas statistiškai reikšmingas sumažėęs depresijos simptomų išreikštumas pacientų, vartojusių intranazalinį esketaminą, lyginant su placebo [22]. Kitų autorių aprašyto TRANSFORM-3 3 fazès, randomizuoto, dvigubai slapto tyrimo metu buvo įvertintas intranazalinio esketamino vartojimo efektyvumas, vyresnių nei $65 \mathrm{~m}$. pacientų grupeje. Lyginant pacientų grupes, atitinkamai vartojusias intranazalinị esketaminą kartu su peroraliniu antidepresantu ir vartojusias placebo su peroraliniu antidepresantu, statistiškai reikšmingo skirtumo nenustatyta. Buvo stebèti statistiškai geresni MADRS depresijos vertinimo skalès įverčiai pacientu, vartojusių intanazalinį esketaminą, grupeje[23]. 2018 m. E. Daly, M. Trivedi ir kt. aprašytame SUSTAIN -1 tyrime, atliktame su teigiamą atsaką i gydymą turejusiais TRANSFORM-1 ir TRANSFORM-2 tyrimų dalyviais, buvo atliktas gydymu pasiektos remisijos laikotarpio įvertinimas. Nustatyta, jog po 16 savaičių intranazalinio esketamino ir geriamojo antidepresanto vartojimo, recidyvo rizika sumažejo 51 procentu intranazalinio esketamino naudai, lyginant su placebo. Stebėti nepageidaujami reiškiniai buvo dizgeuzija, galvos svaigimas, galvos skausmas, atsiribojimas, mieguistumas, pykinimas, neryškus matymas, burnos hipestezija [24]. 2018 m. E. Wajs ir kolegų aprašytame SUSTAIN-2 tyrime taip pat buvo įvertinta nepageidaujamų reakcijų, susijusių su intranazalinio esketamino vartojimu, rizika. Pacientams atitinkamai buvo skiriamos 28, 56 ar 84 miligramų esketamino dozès. Pagrindinis tyrimo tikslas buvo nustatyti gydymo metu atsiradusius nepageidaujamus reiškinius, kurių dauguma buvo lengvi ar vidutinio sunkumo ir apėmé galvos svaigimą, atsiribojimą, pykinimą, galvos skausmą, mieguistumą, dizgeuziją, hipesteziją, vertigo, vėmimą ir virusines viršutinių kvėpavimo takų infekcijas [25]. Tyrimai patvirtina intranazalinio esketamino vartojimo naudingumą gydyti gydymui atsparią depresiją ir didžiajam depresijos sutrikimui, vyraujant suicidinei simptomatikai. Ilgalaikių tyrimų metu nustatyta, jog dauguma pacientų patyrè teigiamą atsaką i gydymą, skiriant $84 \mathrm{mg}$ intranazalinio esketamino 
dozes, o maždaug trečdalis pacientų - skiriant $56 \mathrm{mg}$ dozes, vartojamas kas savaitę ar kas antrą savaitę. Remiantis tyrimų išvadomis, intranazaliai vartojamas esketaminas sumažina savižudybės riziką ir depresijos simptomus[26].

Klinikinès rekomendacijos. Europos vaistų agentūra (EMA) pateikia tokias praktines rekomendacijas [14]:

1. Gydymui atsparios depresijos diagnozè nustatoma nesèkmingai gydant depresiją bent dviem skirtingais antidepresantais tinkamomis dozèmis ir pakankamą gydymo laiką.

2. Esketamino nosies purškalas vartojamas kartu su SSRI ar SNRI grupès antidepresantais. Prieš gydymą svarbu įvertinti paciento depresijos anamnezę ir, atsižvelgiant ị buvusio gydymo efektyvumą, spręsti, ar pradèti gydymą nauju tos pačios klasès antidepresantu, ar paskirti naują, kitos klasès (SSRI ar SNRI) antidepresantą.

3. Rekomenduojama pradinè medikamento dozé - vienas ar du ịpurškimai ị kiekvieną šnervę pirmają gydymo dieną, atsižvelgiant ị paciento amžių. Po to du kartus per savaitę 4 savaites po vieną, du arba tris ịpurškimus ị kiekvieną nosies landą. Vèliau, jei pagerèjo paciento depresijos simptomai, kitas 4 savaites esketaminas vartojamas vieną kartą per savaitę, o po to - kas vieną ar dvi savaites mažiausiai 6 mènesius.

4. Dèl galimo nepageidaujamo poveikio, pavartojęs esketamino pacientas turi būti stebimas medicinos personalo, ypač dèl padidejusio kraujospūdžio, disociacijos ir sedacijos.

Jei po esketamino pavartojimo stebimas padidèjęs paciento kraujospūdis, tikslinga jị toliau stebèti. Jei kraujospūdis išlieka padidèjęs, rekomenduojama skirti antihipertenzini gydymą, kol kraujospūdžio verte normalizuosis. Jei pacientui pasireiškia disociacinis (konversinis) sutrikimas, svarbu stebèti paciento būklę [27]. İprastai specialus ịsikišimas nereikalingas, tačiau retais atvejais, pasireiškus dideliam sujaudinimui ar nerimui, tikslinga apsvarstyti benzodiazepino, pavyzdžiui, lorazepamo skyrimą. Jei pacientui pasireiškia stiprus medikamento sedacinis poveikis arba prarandama sąmonè, rekomenduojama atidžiai stebėti kvejpavimo sistemos slopinimo ir hemodinamikos parametrų pokyčius. Toliau taikant gydymą esketaminu, svarbu apsvarstyti ir ịvertinti nepageidaujamų reiškinių dažnị ir sunkumą, paciento lūkesčius, kartu vartojamus medikamentus ir psichiatrinę paciento anamnezę [27].

\section{Rezultatų aptarimas}

Didysis depresinis sutrikimas yra labai aktuali sveikatos priežiūros problema visame pasaulyje. Prognozuojama, jog šio sutrikimo pasireiškimo dažnis ateityje didès. Maždaug vienam trečdaliui pacientų, sergančių didžiuoju depresiniu sutrikimu, nustatoma gydymui atspari depresija, kai nèra terapinio depresijos gydymo efekto pacientą gydant bent dviem skirtingais antidepresantais, tinkamomis dozemis ir pakankamą gydymo laiką. Gydymui atsparios depresijos problematika skatina naujų depresijos gydymo metodų paiešką. Naujasis rezistentiškai depresijai gydyti skirtas preparatas esketaminas yra daug žadantis preparatas, leidžiantis sumažinti sergančiųu gydymui atsparia depresija simptomų išreikštumą ir suicidinių tendencijų riziką. Vartojant esketaminą, svarbu užtikrinti paciento priežiūrą ir saugumą, gyvybinių funkcijų stebėseną, siekiant užkirsti kelią galimam nepageidaujamam poveikiui.

\section{Išvados}

1. Esketaminas, vartojamas kartu su kitu, naujai paskirtu SSRI ar SNRI grupès geriamuoju antidepresantu, yra efektyvus preparatas, tinkamas gydyti gydymui atsparią depresiją, kai ankstesnès terapijos metu, skiriant gydymą bent dviem skirtingais antidepresantais, tinkamomis dozėmis ir pakankamą gydymo laiką, nebuvo sumažinti išreikšti depresijos simptomai.

2. Pacientams, vartojantiems esketaminą, stebima mažesnè depresijos recidyvo rizika.

3. Esketaminas sumažina gydymui atsparia depresija sergančių pacientų savižudybès riziką.

4. Esketaminas vartojamas sveikatos specialisto priežiūroje. Po preparato inhaliacijos pacientas stebimas 2 valandas ir vertinama, ar nepasireiškia ankstyvieji, po medikamento pavartojimo atsiradandantys nepageidaujami reiškiniai: arterinè hipertenzija, disociaciniai (konversiniai) sutrikimai bei sedacinis poveikis.

5. Užtikrinus tinkamą ankstyvujų nepageidaujamų reiškinių kontrolę ir paciento stebėseną, esketaminas yra saugus preparatas gydyti gydymui atsparią depresiją.

\section{Literatūra}

1. Iqbal SZ, Mathew SJ. Ketamine for depression clinical issues. Adv Pharmacol 2020;89:131-162 doi:10.1016/ bs.apha.2020.02.005

https://doi.org/10.1016/bs.apha.2020.02.005

2. Ng CH, Kato T, Han C, Wang G, Trivedi M, Ramesh V, et al. Definition of treatment-resistant depression - Asia pacific perspectives. Journal Affective Disorders 2019;245, 626-636. https://doi.org/10.1016/j.jad.2018.11.038

3. Holtzheimer PE. Advances in the management of treatment-resistant depression. Focus (Am Psychiatr Publ) 2010;8(4):488-500. https://doi.org/10.1176/foc.8.4.foc 488

4. Ionescu DF, Rosenbaum JF, Alpert JE. Pharmacological approaches to the challenge of treatment-resistant depression. Dialogues Clin Neurosci 2015;17(2):111-126. https://doi.org/10.31887/DCNS.2015.17.2/dionescu

5. Voineskos D, Daskalakis ZJ, Blumberger DM. Management of treatment-resistant depression: challenges and strategies. 
Neuropsychiatr Dis Treat 2020;16:221-234.

https://doi.org/10.2147/NDT.S198774

6. Agboola F, Atlas SJ, Touchette DR, Fazioli K, Pearson SD. The effectiveness and value of esketamine for the management of treatment-resistant depression. J Managed Care Specialty Pharmacy 2020;26(1):16-20.

https://doi.org/10.18553/jmcp.2020.26.1.16

7. Pompili M. Intranasal esketamine and current suicidal ideation with intent in major depression disorder: beat the clock, save a life, start a strategy. Front Psychiatry 2020;11:325.

https://doi.org/10.3389/fpsyt.2020.00325

8. Shrestha R, Pant S, Shrestha A, Batajoo KH, Thapa R, Vaidya $\mathrm{S}$. Intranasal ketamine for the treatment of patients with acute pain in the emergency department. World J Emerg Med 2016;7(1):19-24.

https://doi.org/10.5847/wjem.j.1920-8642.2016.01.003

9. Lapidus KA, Levitch CF, Perez AM, Brallier JW, Parides MK, Soleimani L, Feder A, Iosifescu DV, Charney DS, Murrough JW. A randomized controlled trial of intranasal ketamine in major depressive disorder. Biol Psychiatry 2014;76(12):970-6. https://doi.org/10.1016/j.biopsych.2014.03.026

10. Zhong X, He H, Zhang C, Wang Z, Jiang M, Li Q, Zhang M, Huang XJ. Mood and neuropsychological effects of different doses of ketamine in electroconvulsive therapy for treatmentresistant depression. J Affect Disord 2016;201(1):124-30. https://doi.org/10.1016/j.jad.2016.05.011

11. American Psychiatric Association. Diagnostic and statistical manual of mental disorders (DSM-5). 2013:991.

https://doi.org/10.1176/appi.books.9780890425596

12. Parikh RM, Lebowitz BD. Current perspectives in the management of treatment-resistant depression. Dialogues Clin Neurosci 2004;6(1):53-60.

https://doi.org/10.31887/DCNS.2004.6.1/rparikh

13. Nelsen MR, Dunner DL. Treatment resistance in unipolar depression and other disorders. Diagnostic concerns and treatment possibilities. Psychiatr Clin North Am 1993;16(3):541-66. https://doi.org/10.1016/S0193-953X(18)30164-3

14. https://www.ema.europa.eu/en/medicines/human/EPAR/ spravato

15. Hijazi Y, Bodonian C, Bolon M, Salford F, Boulieu R. Pharmacokinetics and haemodynamics of ketamine in intensive care patients in brain or spinal cord injury. British Journal of Anaesthesia 2003;90:155-6.

https://doi.org/10.1093/bja/aeg028

16. Perez-Ruixo C, Rossenu S, Zannikos P, Nandy P, Singh J, Drevets WC, Perez-Ruixo JJ. Population pharmacokinetics of esketamine nasal spray and its metabolite noresketamine in healthy subjects and patients with treatment-resistant depression. Clinical Pharmacokinetics 2021;60(4):501-516.

https://doi.org/10.1007/s40262-020-00953-4

17. Maeng S, Zarate CA. The role of glutamate in mood disorders: results from the ketamine in major depression study and the presumed cellular mechanism underlying its antidepressant effects. Current Psychiatry Reports 2007;9(6):467-474.

https://doi.org/10.1007/s11920-007-0063-1

18. Covvey JR, Crawford AN, Lowe DK. Intravenous ketamine for treatment-resistant major depressive disorder. Annals of Pharmacotherapy 2012;46(1):117-123.

https://doi.org/10.1345/aph.1Q371

19. Khorassani F, Talreja O. Intranasal esketamine: a novel drug for treatment-resistant depression. American Journal HealthSystem Pharmacy. 2020 ;77(17):1382-1388.

https://doi.org/10.1093/ajhp/zxaa191

20. Daly EJ, Singh JB, Fedgchin M, Cooper K, Lim P, Shelton RC, Thase ME, Winokur A, Van Nueten L, Manji H, Drevets WC. Efficacy and safety of intranasal esketamine adjunctive to oral antidepressant therapy in treatment-resistant depression: a randomized clinical trial. JAMA Psychiatry 2018; 75(2):139-148. https://doi.org/10.1001/jamapsychiatry.2017.3739

21. Canuso CM, Singh JB, Fedgchin M, Alphs L, Lane R, Lim P, Pinter C, Hough D, Sanacora G, Manji H, Drevets WC. Efficacy and safety of intranasal esketamine for the rapid reduction of symptoms of depression and suicidality in patients at imminent risk for suicide: results of a double-blind, randomized, placebocontrolled study. Am J Psychiatry 2018;175(7):620-630 https://doi.org/10.1176/appi.ajp.2018.17060720

22. Popova V, Daly E, Trivedi M, et al. Randomized, double-blind study of flexibly-dosed intranasal esketamine plus oral antidepressant vs. active control in treatment-resistant depression. Poster presented at American Psychiatric Association Annual Meeting 2018. Abstract in Biol Psychiatry 2018;83(suppl 9):S390.

https://doi.org/10.1016/j.biopsych.2018.02.1002

23. Ochs-Ross R, Daly EJ, Trivedi M, et al. Efficacy and safety of intranasal esketamine plus an oral antidepressant in elderly patients with treatment-resistant depression. Poster presented at American Psychiatric Association Annual Meeting 2018. Abstract in Biol Psychiatry 2018;83(suppl 9):S391. https://doi.org/10.1016/j.biopsych.2018.02.1005

24. Daly E, Trivedi M, Janik A, et al. A randomized withdrawal, double-blind, multicenter study of esketamine nasal spray plus an oral antidepressant for relapse prevention in treatmentresistant depression. Poster presented at American Society of Clinical Psychopharmacology Annual Meeting 2018.

25. Wajs E, Aluisio L, Morrison R, et al. Long-term safety of esketamine nasal spray plus oral antidepressant in patients with treatment-resistant depression: phase 3, open-label, safety and efficacy study (SUSTAIN-2). Poster presented at American Society of Clinical Psychopharmacology Annual Meeting 2018. https://doi.org/10.1016/j.euroneuro.2018.11.1016

26. Bahr R, Lopez A, Rey JA. Intranasal esketamine (SpravatoTM) for use in treatment-resistant depression in conjunction with an oral antidepressant. PT 2019;44(6):340-375. 
27. Kasper S, Cubała WJ, Fagiolini A, Ramos-Quiroga JA, Souery D, Young AH. Practical recommendations for the management of treatment-resistant depression with esketamine nasal spray therapy: basic science, evidence-based knowledge and expert guidance. World J Biol Psych 2020:1-45.

https://doi.org/10.1080/15622975.2020.1836399

\section{ESKETAMINE AND TREATMENT-RESISTANT DEPRESSION \\ V. Grigas}

Keywords: major depressive disorder, treatment-resistant depression, esketamine.

Summary

Aim of the study. To review and summarize evidence-based medical data on the utility and application of the drug esketamine in the treatment of treatment-resistant depression. To review the pharmacological mechanism of action of the drug, its clinical utility and to provide clinical recommendations for the administration of the medication to ensure proper and safe use of the drug.

Methodology. A search for thematic scientific articles was performed in Pubmed, SpringerLink databases using keywords: major depressive disorder, treatment-resistant depression, esketamine. From more than 70 scientific publications, 30 articles were selected. Results. The problem of treatment-resistant depression is na- med. The mechanism of action, pharmacological properties, clinical utility of the drug used in the treatment of treatment-resistant depression, as well as clinical recommendations for specialists in their practice prescribing esketamine to patients are reviewed. Conclusions. Esketamine, when co-administered with another newly prescribed SSRI or SNRI oral antidepressant, is an effective treatment for refractory depression when previous treatment with at least two different antidepressants, using appropriate doses, and sufficient duration of treatment has not reduced the symptoms of depression. Patients taking esketamine have a lower risk of recurrence of depression. Esketamine reduces the risk of suicide in patients with treatment-resistant depression. The drug is used under the supervision of a healthcare professional. After inhalation, the patient is observed for 2 hours and is assessed for early post-dose adverse events: arterial hypertension, dissociative (conversion) disorders and sedative effects. With adequate control of early adverse events and patient monitoring, esketamine is a safe treatment for refractory depression.

Correspondence to: vidmantasgrigas@gmail.com

Gauta 2021-05-05 